\title{
Impact of Cleaner Production and Environmental Management on Sustainable Product Innovation and Performance: A study of Manufacturing Industry of Iran
}

\author{
Mahmood Zohoori \\ Master of Environmental \\ Management \\ Putra University of Malaysia \\ Birjand, Iran
}

\author{
Ali Ghani \\ Master of Business \\ Administration (MBA) \\ Industrial Management Institute \\ Birjand, Iran
}

\author{
Hojat Zakeri \\ Master of Environmental \\ Pollution \\ Islamic Azad University, \\ Science and Research Branch, \\ Birjand, Iran
}

\begin{abstract}
By review of previous research, cleaner production (CL) and environmental management (EM) can improve sustainable product innovation (SPI) and thereby company's performance (financial/non-financial). This study is trying to measure the impact of cleaner production and environmental management on sustainable product innovation and company's performance while performance includes four perspectives according to the balanced scorecard (BSC) model. The proposed perspectives of BSC consist of financial performance, customer satisfaction, internal process, and learning and growth. 255 data were gathered from 10 large manufacturing companies of Iran. The outcome of regression analysis showed that CP has significant impact on customer satisfaction, financial performance, and learning growth. Besides, EM only affects customer satisfaction and internal process significantly and positively. Except financial performance all perspectives of performance can be affected by SPI.
\end{abstract}

Keywords: Performance, Balanced Scorecard, Cleaner Production, Environmental Management, Sustainable Product Innovation, Iran

\section{INTRODUCTION}

According to the conducted research by scholars of current study which is published in this issue, cleaner production and environmental management have high potential which impacts sustainable product innovation and organizational performance. According to BSC's model (Kaplan and Norton, 1997), there are four perspectives to evaluate the performance of a company including, financial, customer satisfaction, internal process, and learning and growth (L\&G). Recent scholars (e.g. Hojabri et al., 2013; Manafi and Subramaniam, 2015) also believe that these four perspectives can measure company performance properly.

The Environmental Management (EM) practices and also Cleaner Production (CP) techniques are proper tools which aim for efficiency in process of production, using the inputs and also generating industrial wastes. Such tools could remarkably help to Sustainable Product Innovation (SPI) because of rational utilization of natural resources and also reduction of generated waste. Also, sustainable product innovation comes as an opportunity in order to launch new products on market which can meet the imposed pressures by global society as well as legislation (Severo et al., 2017).
Severo et al. (2017) believe that cleaner production and environmental management can affect SPI and thereby financial performance. However, nonfinancial performance also can be affected by these factors when non-financial consists of customer satisfaction, learning and growth, and internal process (as it is presented in the research of Kaplan and Norton (1997), Hojabri et al. (2013), and Manafi and Subramaniam (2015)). The reason is that cleaner production and EM include knowledge and experience which can affect learning and growth and also internal process. Obviously, customer satisfaction will be affected by learning and growth and internal process. So, this study aims to examine how cleaner production and EM affect SPI and different perspectives of performance.

\section{LITERATURE REVIEW}

Innovation could be as some changes in services and products and also the way they are supposed to be produced or being offered to market. Hence, innovation is described as developing and implementing new ideas that would be a collective outcome (Van De Ven, 1986; Van De Ven et al., 1989; Gracia and Calantone, 2002). Here, innovating the sustainable products could be identified as presenting new or remarkably improved goods or services, with considering its specific characteristics or intended usages from previously produced products by companies 
(Balachandra and Friar, 1997). It should focus on environmental requirements in order to minimize exploitation of natural resources, energy, water, material, production processes improvements and also those environmental practices which reduce effects on environment and minimizes production of pollutants and waste (Placet et al., 2005; Potts, 2010).

The Cleaner Production (CP) technology means using and developing new techniques, methods, energy sources and materials which reduce production waste and within the life cycle of the product (Dunn and Bush, 2001; Tseng et al., 2009; Yonga et al., 2016). The CP methodologies have been developed by the Industrial Development Organization and also Environment Programmes of the United Nations, hence organizations systematically can minimize their emissions and waste (Kliopova and Staniskis, 2006; Hicks and Dietmar, 2007; Lukena et al., 2016).

The environmental sustainability quest is currently transforming competitive landscape, demands to business modifications in products development, technologies, processes and also business models as well as initiating rational utilization of natural resources, treating them and providing the generated waste properly in order to preserve environment (Severo, 2013).

In context of an organization, the related environmental practices to processes and product development, help to sustainable development, offering organizations more economic stability and environmental sustainability. Thus, companies are able to reduce environmental effects through utilizing the environmental management technologies, including: Effluent Treatment Plant (WWTP), Waste Management System (SGR), Life Cycle Analysis (LCA), Environmental Management System (EMS) ISO 14001, Cleaner Production (CP), Industrial Symbiosis (IS), Industrial Ecology (IE), recycling, etc. (Anton et al., 2004; Chertow, 2007; Darnall et al., 2008).

\section{Research Methodology and Developed Hypothesis}

According to Severo et al. (2017) and Przychodzen (2015), generally eco-innovations were considered with more return on the equity and assets. Moreover, organizations which present ecoinnovations also were remarkably showing more performant levels and encountered with less financial risk and have more available cash flow compared to the conventional organizations. On the other hand, they agree that EM and CP both can impact the financial performance. Additionally, Cheng et al. (2014) mentioned that sustainable innovation has strong impact on business performance in Taiwanese firms.

As mentioned above, $\mathrm{CP}$ and $\mathrm{EM}$ have high potential to influence SPI and non-financial performance as well. Consequently, we will have following hypotheses:

\section{H1: CP affects SPI significantly and positively \\ H2: EM affects SPI significantly and positively}

H3: CP affects financial performance significantly and positively

H4: EM affects financial performance significantly and positively

H5: CP affects customer satisfaction significantly and positively

H6: EM affects customer satisfaction significantly and positively

$\mathrm{H} 7$ : CP affects learning and growth significantly and positively

H8: EM affects learning and growth significantly and positively

H9: CP affects internal process significantly and positively

H10: EM affects internal process significantly and positively

H11: SPI affects financial performance significantly and positively

H12: SPI affects customer satisfaction significantly and positively

H13: SPI affects learning and growth significantly and positively

H14: SPI affects internal process significantly and positively

In order to test above hypotheses, 10 large manufacturing companies in Iran were chosen. 300 questionnaires were distributed among managers (top/middle) and expert engineers and employee of R\&D departments. At the end 255 usable questionnaires were received. This survey 
was carried out on 2016. The next part will show the results of data analyzing by SPSS 22 .

\section{Data analysis and Discussion}

Table 1 demonstrates the demographic information of 255 respondents of this study. According to this table, the frequency of male (141) is greater than frequency of female (114).

Table 1: Demographics

\begin{tabular}{|c|c|c|}
\hline & Frequency & Percentage \\
\hline Gender & & \\
\hline Male & 141 & 55.3 \\
\hline Female & 114 & 44.7 \\
\hline Age & & \\
\hline Less than 18 & 0.00 & $0.00 \%$ \\
\hline $19-25$ & 27 & $10.86 \%$ \\
\hline $26-40$ & 122 & $47.8 \%$ \\
\hline $\begin{array}{l}\text { Greater than } \\
45\end{array}$ & 106 & $41.5 \%$ \\
\hline Education & & \\
\hline $\begin{array}{l}\text { Diploma or } \\
\text { below }\end{array}$ & 3 & $1.1 \%$ \\
\hline Bachelor & 88 & $34.5 \%$ \\
\hline $\begin{array}{l}\text { Master or } \\
\text { higher }\end{array}$ & 164 & $64.3 \%$ \\
\hline Salary & & \\
\hline $\begin{array}{l}\text { Less than } 500 \\
\$\end{array}$ & 0.00 & $0.00 \%$ \\
\hline $501-1000 \$$ & 22 & $8.62 \%$ \\
\hline $\begin{array}{l}\text { More than } \\
1001 \$\end{array}$ & 233 & $91.3 \%$ \\
\hline
\end{tabular}

The highest frequency (122) of age refers to 26-45 while the lowest frequency $(0.00)$ is for less than 18. Out of 255 respondents, 164 respondents are working with master or doctorate degree while the frequency of diploma and bachelors totally is equal to 91. Regarding the salaries, 233 of respondents receive more than $\$ 1001$ monthly while others' salaries are less than $\$ 1001$.

Table 2 shows the central indicators of mean analysis for each variable.

\begin{tabular}{|c|c|c|c|c|c|c|c|}
\hline & 5 & Wan & Sid Driata & Somsex & & Sirtris & \\
\hline & Sthitse & tarsis: & Strthist & Satsos: & SH Emor & Stritse & SHE Em \\
\hline Q & 235 & 3.130 & LaH39 & 333 & 138 & -109 & 304 \\
\hline$B$ & 235 & 2995 & La6s & 136 & 138 & -1169 & 304 \\
\hline Frail?dinume & 235 & 3.910 & LESW & $n$ & 138 & -1162 & 304 \\
\hline terring i Gouth & 255 & 30.24! & 1047 & 231 & $18 \%$ & -1199 & $M$ \\
\hline Se] & 255 & 31710 & Lit62: & 317 & 138 & -1246 & Sa \\
\hline Stanal Proces & 25 & 3.1 .24 & LEWW & 32 & 158 & $-19 \mathrm{y}$ & SH \\
\hline Cubar saitatim & 255 & 3.1697 & Lomi16 & 324 & 138 & $-16 \% ?$ & $M$ \\
\hline 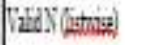 & 235 & & & & & & \\
\hline
\end{tabular}

Thlth: Coretentes:

\begin{tabular}{|c|c|c|c|c|c|c|c|c|}
\hline & & g & DI & WF & $\begin{array}{l}\text { Frasial } \\
\text { Petromese }\end{array}$ & $\begin{array}{l}\text { Costwe } \\
\text { iffíctum }\end{array}$ & $\pm N G$ & $\begin{array}{l}\text { Irten: } \\
\text { invee: }\end{array}$ \\
\hline \multirow[t]{2}{*}{$p$} & PassoConditur & 1 & $388^{\circ}$ & .76 & $x^{2}$ & 518 & $76^{\circ}$ & $30^{\circ}$ \\
\hline & Sis. $(2 . t x)$ & & mo & $m$ & $m$ & m & 100 & $m$ \\
\hline \multirow[t]{2}{*}{ SI } & Parsechonition & $3 w^{\prime}$ & 1 & $3 W^{\circ}$ & $34]^{*}$ & $22^{4}$ & 21 & $18 g^{\prime}$ \\
\hline & Sescotile & $\infty$ & & $m$ & $\infty 0$ & 100 & ail & MH \\
\hline \multirow[t]{2}{*}{ S } & PassuComation & 766 & $380^{\prime \prime}$ & 1 & $280^{\circ}$ & $62^{\prime \prime}$ & $50^{\circ}$ & $30^{\circ}$ \\
\hline & isg (-talix) & $\infty$ & $m$ & & mo & m & $m$ & $\infty$ \\
\hline \multirow{2}{*}{ Pedrovian: } & Parvelonition & $36^{n}$ & $344^{\prime \prime}$ & $45^{\circ}$ & 1 & $133^{\circ}$ & 115 & 24 \\
\hline & $\lg (-\operatorname{tal})$ & $\infty$ & 1000 & $M$ & & $\mathbb{M}$ & DHS & 200 \\
\hline \multirow{2}{*}{$\begin{array}{l}\text { Critueg } \\
\text { tustation }\end{array}$} & Passoconditio & $515^{5}$ & $w^{+}$ & बा & 139 & I & $360^{\circ}$ & -182 \\
\hline & $\operatorname{ls}(\operatorname{ctalix})$ & $\infty$ & $m$ & $m$ & 6 & & oco & 14 \\
\hline \multirow[t]{2}{*}{ HEG } & Passelmalize & $5 \mathrm{~F}^{-}$ & $2 I^{\prime}$ & $60^{\circ}$ & 115 & $566^{\prime \prime}$ & 1 & $\infty 8$ \\
\hline & is $(1+2)$ & $\mathscr{W}$ & $\mathbb{1}$ & 1000 & .045 & $m$ & & st \\
\hline \multirow[t]{2}{*}{ seal hous } & ParseConitio & $W^{\circ}$ & $18^{\circ}$ & $30^{\circ}$ & 24 & .12 & Min & 1 \\
\hline & 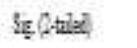 & 001 & 14 & 1000 & $\infty$ & IH & s4 & \\
\hline
\end{tabular}


Inlet Creshise:

\begin{tabular}{|c|c|c|c|c|c|c|c|c|}
\hline & & $\theta$ & BI & PI & Ganced & $\begin{array}{l}\text { Cossons } \\
\text { zitidatan }\end{array}$ & LESE & $\begin{array}{l}\text { fend } \\
\text { these }\end{array}$ \\
\hline \multirow[t]{2}{*}{$Q$} & Persularden & : & $38^{\circ}$ & $766^{\circ}$ & $x^{\circ}$ & 35 & $\sqrt{56}$ & $300^{\circ}$ \\
\hline & $\mathrm{Sig}(\mathrm{ftal})$ & & 100 & 100 & $\infty 0$ & (ivi) & in & an \\
\hline \multirow[t]{2}{*}{ 2!! } & Passularditon & $35^{\circ}$ & 1 & $200^{-1}$ & $344^{\circ}$ & $22^{2}$ & $2 y^{4}$ & $199^{\prime}$ \\
\hline & Seg (taled & m & & 200 & $\infty 00$ & M & $\mathbb{M}$ & oH \\
\hline \multirow[t]{2}{*}{$x$} & Alessulondan & 166 & $300^{\circ}$ & I & 65 & $\mathrm{~S}^{2}$ & $\pi \pi^{\circ}$ & $39^{\circ}$ \\
\hline & 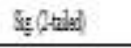 & M & 100 & & 00 & M & 100 & 00 \\
\hline \multirow{2}{*}{ Fand } & Persulonden & 35 & $\left.3\right|^{2}$ & $15^{5}$ & 1 & 139 & $18^{\prime}$ & $w$ \\
\hline & 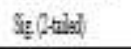 & $m$ & (a) & 200 & & $\omega$ & of & $\infty 0$ \\
\hline \multirow{2}{*}{ 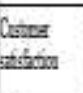 } & ?ara Curdete & $5 \mathrm{Hi}^{+}$ & 27 & $5^{2}$ & $1 y^{\prime}$ & I & $566^{\circ}$ & $M$ \\
\hline & Se(thilas) & m & 1000 & 200 & $m$ & & $(10)$ & 14 \\
\hline \multirow[t]{2}{*}{186} & Zussulardata & 53 & $211^{\prime}$ & 5 & $11^{2}$ & $i 6^{\circ}$ & I & 180 \\
\hline & Sef (talis) & $m$ & (m) & 00 & ath & in & & $g$ \\
\hline \multicolumn{2}{|c|}{ 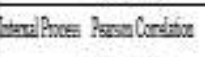 } & $x^{4}$ & $1 W^{+}$ & $3)^{\prime \prime}$ & $y^{\circ}$ & $-M$ & 160 & 1 \\
\hline & 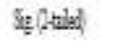 & 100. & 1.4. & 20 & 00 & 14 & 54 & \\
\hline
\end{tabular}

Referring to the table 3, CP and EM have significant relationships with SPI and all performance's perspectives. The highest estimated correlation value refers to CP and SPI (.766) while the lowest value is (.189) referred to relationship between EM and internal process. Besides, SPI has significant relationship with all variables.

Table 4: Regression Analyses Results

\begin{tabular}{|c|c|c|c|c|c|}
\hline Ellest & Hoxtease & Coenswart & R.Symen & Fiabs & Ecrourad \\
\hline \multirow{2}{*}{ 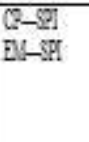 } & \multirow{2}{*}{ 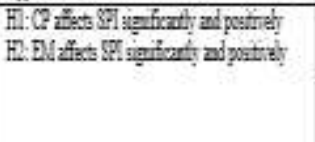 } & 212 & \multirow{2}{*}{655} & $2 x$ & $\mathrm{Te}$ \\
\hline & & in & & WI & Pes \\
\hline \multirow[t]{2}{*}{ 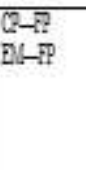 } & \multirow{2}{*}{ 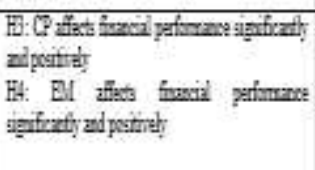 } & 235 & \multirow{2}{*}{564} & $M$ & Te \\
\hline & & MI & & 163 & $\mathrm{Nb}$ \\
\hline \multirow[t]{2}{*}{$\begin{array}{l}2-C S \\
2 C-C B\end{array}$} & \multirow{2}{*}{ 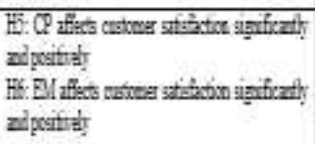 } & 331 & \multirow{2}{*}{.44 } & 20 & Te: \\
\hline & & $m$ & & $(6)$ & No \\
\hline \multirow[t]{2}{*}{$\begin{array}{l}\text { C2-ISG } \\
\text { DLLISG }\end{array}$} & \multirow{2}{*}{ 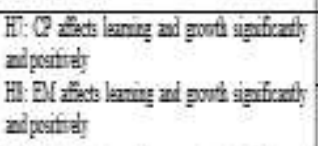 } & 277 & \multirow{2}{*}{512} & WI & $\mathrm{Te}$ \\
\hline & & 32 & & $\mathbb{N}$ & Pes \\
\hline \multirow[t]{2}{*}{$\begin{array}{l}0-2 \\
2,-7\end{array}$} & \multirow{2}{*}{ 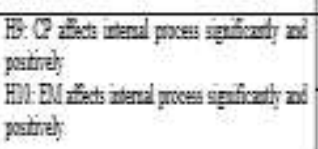 } & 156 & \multirow[b]{2}{*}{.46} & $M$ & $\mathrm{No}$ \\
\hline & & 321 & & 20 & Tes \\
\hline 3PI-F & 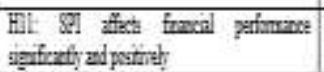 & 19 & .111 & 97 & No \\
\hline $3 \pi-\infty$ & 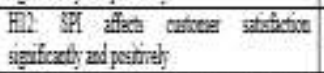 & . 51 ! & 604 & $2 \mathrm{~N}$ & Tes \\
\hline SID-ASG & 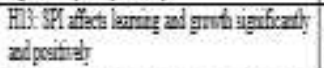 & 23 & .701 & $m 6$ & Te \\
\hline W-2 & 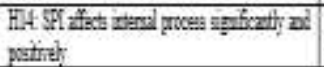 & 361 & 660 & $\mathrm{M}$ & Tet \\
\hline
\end{tabular}

Based on the developed hypotheses of this study, nine regression analyses were done. Table4 shows the results of hypothesis testing. Except H4, H6, $\mathrm{H} 9$, H11, other hypotheses are supported by this study.

As shown in Table 4, cleaner production has significant impacts on customer satisfaction, financial performance and learning and growth while it does not have significant impact on internal process. This result can be considered as a contribution of this study.

As another contribution of this study, EM has significant impacts on learning and growth and internal process.

The outcome of regression analysis showed that except financial performance other perspectives of performance can be affected by SPI significantly and positively. This result is inconsistent with the research conducted by Severo et al. (2017).

\section{Conclusion}

By review of previous research, cleaner production and environmental management can improve sustainable product innovation and thereby company's performance (financial/non-financial). This study attempted to measure the impact of cleaner production and environmental management on sustainable product innovation and company's performance while performance includes four perspectives according to the balanced scorecard model. The proposed perspectives of BSC consist of financial performance, customer satisfaction, internal process, and learning and growth. 255 data were gathered from 10 large manufacturing companies of Iran. The outcome of regression analysis showed that $\mathrm{CP}$ has significant impact on customer satisfaction, financial performance, and learning growth. Besides, EM only affects customer satisfaction and internal process significantly and positively. Except financial performance all perspectives of performance can be affected by SPI.

\section{References}

Anton, W.R.Q., Deltas, G., Khanna, M., 2004. Incentives for environmental selfregulation and implications for environmental performance. J. Environ. Econ. Manag. 48 (1), $632 \mathrm{e} 654$.

Balachandra, R., Friar, J.H., 1997. Factors for Success in R\&D Projects and New Product Innovation: a Contextual Framework. IEEE Trans. Eng. Manage. N. J. 44 (3), 276-287. 
Cheng, C.C.J., Yang, C-1., Sheu, C., 2014. The link between eco-innovation and business performance: a Taiwanese industry context. J. Clean. Prod. 64, 81-90.

Chertow, M.R., 2007. Unconvering industrial symbiosis. J. Industrial Ecol. New Haven 1 (1), 11-30.

Darnall, N., Jolley, G.J., Handfield, R., 2008. Environmental management systems and green supply chain management: complements for sustainability? Bus. Strategy Environ. 17 (1), $30-45$.

Dunn, R.F., Bush, G.E., 2001. Using process integration for cleaner production. J. Clean. Prod. 9, 1-13.

Elkington, J., 1999. Cannibals with Forks. New Society, Canada.

Garcia, R., Calantone, R., 2002. A critical look at technological innovation typology and innovativeness terminology: a literature review. J. Prod. Innovation Manag. 19 (2), 110-132.

Hicks, C., Dietmar, R., 2007. Improving cleaner production through the application of environmental management tools in China. J. Clean. Prod. 15, 395-408.

Hojabri, R., Manafi, M., Eftekhar, F., Ghassemzadeh, H., Sharifi, M. and Kaliannan, M., 2013. Effective methods for health care organizations: An evaluation of excellence models. African Journal of Business Management, 7(27), p. 2665 .

Kaplan, R.S. and Norton, D.P., 1997. Balanced ScorecardStrategien erfolgreich umsetzen.

Kliopova, I., Staniskis, J.K., 2006. The evaluation of cleaner production performance in Lithuanian industries. J. Clean. Prod. 14, 1561-1575.

Lukena, R.A., Van Berkelb, R., Leuenbergerc, H., Schwagerb, P., 2016. A 20-year retrospective of the national cleaner production centres programme. J. Clean. Prod. 112, 11651174.

Manafi, M. and Subramaniam, I.D., 2015. Balancing performance by human resource management practices. Asian Social Science, 11(10), p.386.

Placet, M., Anderson, R., Fowler, K.M., 2005. Strategies for sustainability: innovation and customization are critical, studies for the cement industry and state of Arizona reveal. ResearchTechnologyManagement 48 (5), 32-41.

Przychodzen, J., Przychodzen, W., 2015. Relationships between eco-innovation and financial performance: evidence from publicly traded companies in Poland and Hungary. J. Clean. Prod. 90, 253-263.

Potts, T., 2010. The natural advantage of regions: linking sustainability, innovation, and regional development in Australia. J. Clean. Prod. 18 (8), 713-725.

Severo, E.A., 2013. Innovation and Environmental Sustainability in the Automotive Companies of the Metal Mechanic Cluster Located in the Serra Gaúcha. Thesis (Doctorate in Business Administration). Postgraduate
Programme Doctorate in Business Administration, Pontificate Catholic University of Rio Grande do Sul/University of Caxias do Sul (accessed in April 2016). https://repositorio.ucs.br/jspui/bitstream/11338/676/1/Tese $\% 2$ 0Eliana\%20Andrea\%20Severo.pdf.

Severo, E. A., de Guimarães, J. C. F., \& Dorion, E. C. H., 2017. Cleaner production and environmental management as sustainable product innovation antecedents: A survey in Brazilian industries. Journal of Cleaner Production, 142, 8797.

Tseng, M.L., Lin, Y.H., Chiu, A.S.F., 2009. Fuzzy AHPbased study of cleaner production implementation in Taiwan PWB manufacturer. J. Clean. Prod. 17 (14), 1249-1256.

Van De Ven, A.H., 1986. Central problems in the management of innovation. Manag. Sci. 32 (5), 590-607.

Van De Ven, A.H., Angle, H.L., Poole, M.S., 1989. Research on the Management of Innovation: the Minnesota Studies. Harper \& Row, New York.

Van Hoff, B., Lyon, T.P., 2013. Cleaner production in small firms taking part in Mexico's Sustainable Supplier Program. J. Clean. Prod. 41, 270-282.

Van Hoof, B., 2014. Organizational learning in cleaner production among Mexican supply networks. J. Clean. Prod. $64,115-124$.

Yonga, J.Y., Klemesa, J.J., Varbanova, P.S., Huisinghb, D., 2016. Cleaner energy for cleaner production: modelling, simulation, optimisation and waste management. J. Clean. Prod. 111, 1-16. 